\title{
Leibniz and the Puzzle of Incompossibility: The Packing Strategy
}

\section{Citation}

McDonough, Jeffrey K. 2010. Leibniz and the puzzle of incompossibility: The packing strategy. Philosophical Review 119(2): 135-163.

\section{Published Version}

doi:10.1215/00318108-2009-035

\section{Permanent link}

http://nrs.harvard.edu/urn-3:HUL.InstRepos:4306694

\section{Terms of Use}

This article was downloaded from Harvard University's DASH repository, and is made available under the terms and conditions applicable to Open Access Policy Articles, as set forth at http:// nrs.harvard.edu/urn-3:HUL.InstRepos:dash.current.terms-of-use\#OAP

\section{Share Your Story}

The Harvard community has made this article openly available.

Please share how this access benefits you. Submit a story.

Accessibility 


\section{Leibniz and the Puzzle of Incompossibility: The Packing Strategy}

Jeffrey K. McDonough

Harvard University

\section{Introduction}

Leibniz famously maintains that God has created the best of all possible worlds. Not surprisingly, it is often objected that other possible worlds seem better and so that a benevolent, all-powerful God should have created a different world instead. But there is in some ways a more fundamental difficulty facing Leibniz's modal ontology: even granting that this is the best of all possible worlds, and that God has done something good in creating it, why doesn't God instantiate other possible worlds as well. Why, that is, doesn't he create not only the best of all possible worlds, but also the second best, the third best, etc.? ${ }^{1}$ After all, Leibniz maintains that existence itself is good, and seems committed to the view that no substance per se entails the existence or non-existence of any other substance. It appears to follow that a wholly good and omnipotent God should want - and be able - to create together every possible substance, and in doing so every possible world. But that, it seems, would leave no unrealized possibilities, and thus no alternatives to what God actually creates. In this way, as in so many others, Leibniz's commitments appear to push him towards a Spinozistic necessitarianism that he was anxious to avoid. ${ }^{2}$

In response to this particular version of the threat of Spinozism, Leibniz suggests that not all possible substances are compossible - that they can't all be created together and thus that not all possible worlds are compossible - that they can't all be created together. 
But while Leibniz's reasons for insisting on the incompossiblity of substances are clear enough, how such a response might be reconciled with the broader commitments of his philosophical system remains obscure. What is needed, most specifically, is an account of how Leibniz might avoid falling into the trap of necessitarianism, while preserving his commitment to the per se independence of created substances and the traditional doctrine of the equivalence of being and goodness.

The following four main sections develop an overlooked strategy for solving the "puzzle of incompossibility." The first section frames the puzzle more carefully and briefly argues that the two dominant strategies developed by Leibniz's commentators fail to solve it fully insofar as they require abandoning one or another of the theses that motivate it. The second section highlights an alternative strategy suggested by Leibniz's guiding analogy of a finite geometrical packing or tiling problem. The third section shows how that strategy might be applied to solve the puzzle of incompossibility in the context of infinite worlds composed of extended corporeal substances. Finally, the fourth section shows how the strategy of Leibniz's packing analogy might be applied even in the context of a thoroughly idealist metaphysics in which the only true substances are non-extended, mind-like "monads." The essay concludes by drawing some connections between Leibniz's thinking about the puzzle of incompossibility and the development of his views concerning the status of corporeal substances.

\section{The Puzzle of Incompossibility}

The puzzle of incompossibility arises most directly in Leibniz's philosophy from the intersection of three central theses. What we might call the thesis of maximization suggests 
that God creates as much being as he can - that he literally maximizes existence. Thus, for example, in a suggestive piece from quite early in his career (1676), Leibniz writes:

After due consideration I take as a principle the harmony of things: that is, that the greatest amount of essence that can exist, does exist. It follows that there is more reason for existing than not existing, and that all things will exist, if that can come about. For since something exists, and all possibles cannot exist, it follows that those things exist which contain the most essence, for there is no other reason for choosing some and excluding the rest. (A.VI.iii.472/DSR 21-2; cf. G VII 302-8/L 486-491; G I 331/L 211; G VII 290/RM 9-10)

Although Leibniz's commitment to maximization might seem somewhat surprising today, it is strongly encouraged by two once widely held doctrines that Leibniz also accepts: on the one hand, that God is wholly good and omnipotent, and, on the other hand, that reality or being is in some sense identical - or "convertible" - with the good. ${ }^{3}$ For if being itself is good, then it seems that a wholly good divinity ought to strive to create as much being as it can, and if that divinity is also omnipotent, it seems that he ought to be able to create as much being as his nature allows.

The second thesis - what we might call the thesis of independence - is likewise rooted in a deeply traditional view, namely, that a substance is a being that exists "in itself (in se) and by itself (per se)." ${ }^{4}$ In discussing this traditional scholastic formula, Jorge Gracia helpfully explains:

It ... meant that a substance was, from its own essence, independent, i.e. that it did not receive its being except through its own essence or form. Of course, all substances are in one way or another dependent on other substances for their efficient causation, and, according to scholastics, on God for their creation. But for 
their formal causation they do not depend on anything else, since there is no reference to other substances or beings in their definition. In this way they differ from accidents which are always defined in terms of another and, therefore, are dependent [per se] on something else..$^{5}(268)$

The independence thesis thus insists that one created substance cannot depend per se upon another created substance - that, if you like, it cannot be written into the formal nature or essence of a created substance that it can only exist with or without some other created substance. Importantly, independence in this sense leaves open the possibility that one substance might nonetheless be dependent upon another substance per accidens. The plants in my garden, for example, are dependent per accidens upon me as an efficient cause, and upon the soil as a material cause, as well as upon the absence of weeds and arsenic that would kill them. Nonetheless, the plants are formally distinct from these things, and all other created substances, and are thus independent per se in the relevant sense. ${ }^{6}$

Although the notion that a created substance must be independent per se was widely held by Leibniz's predecessors and contemporaries, he shows an especially keen interest in drawing out the consequences of this traditional doctrine, and it serves as the driving force behind many of his most important and familiar metaphysical commitments. Thus, for example, it may be seen as the motivation behind the familiar Leibnizian doctrines that substances are individuated by their internal features, that relations between substances supervene on their (cognized) intrinsic properties, and that to each genuine substance there corresponds a complete concept containing only monadic predicates. It is captured succinctly by Leibniz's claim that "each substance is like a world apart, independent of all other things, except for God" (DM 14/AG 47). ${ }^{7}$ 
The third thesis - what we might call the thesis of alternatives - insists that God's free creation presupposes his recognition of different possible worlds. This thesis is of particular importance for Leibniz insofar as he sees it as essential for resisting the threat of a Spinozistic necessitarianism. Thus, in a short piece entitled "On Freedom," tentatively dated to 1689, Leibniz tells us:

... I was [once] very close to the view of those who think that everything is absolutely necessary, who judge that it is enough for freedom that we be uncoerced, even though we might be subject to necessity, and close to the view of those who do not distinguish what is infallible or certainly known to be true, from that which is necessary.

But the consideration of possibles, which are not, were not, and will not be, brought me back from this precipice. For if there are certain possibles that never exist, then the things that exist, at any rate, are not always necessary, for otherwise it would be impossible for others to exist in their place, and thus, everything that never exists would be impossible. (A VI.iv.1653-54/AG 94).

Similarly, in his fifth letter to Samuel Clarke (ca. 1716), Leibniz writes:

$[\mathrm{W}]$ hen a wise being, and especially God, who has supreme wisdom, chooses what is best, he is not the less free upon that account: on the contrary, it is the most perfect liberty, not to be hindered from acting in the best manner... But if what he chooses was absolutely necessary; any other way would be impossible: which is against the hypothesis. For God chooses among possibles, that is, among many ways, none of which implies a contradiction. (G VII 390/Alexander 56-7)

Leibniz is willing to allow that God chooses to instantiate the best of all possible worlds through a sort of moral determination: given the goodness of his character, it is inevitable 
that God chooses to create the best, and we may therefore be morally certain that this is the best of all possible worlds. Nonetheless, Leibniz insists that God's freedom requires there to be alternatives to the actual world (AG 242-43/A II.i.501-2).

The difficulty presented by the puzzle of incompossibility can be located in the fact that, although Leibniz appears to be deeply committed to the theses maximization, independence and alternatives, it is not at all clear that they form a consistent triad. One might, for example, reconcile maximization and independence by supposing that God creates every possible substance, and thereby every possible world; but this would seem to contradict the thesis of alternatives since it would seem to leave no possibility unrealized. Likewise, one might reconcile independence and alternatives by supposing that, although God could create every possible substance, and thereby every possible world, he limits himself to creating some subset of possible substances; but this suggestion seems quite clearly to violate Leibniz's commitment to maximization. Finally, one might reconcile maximization and alternatives by supposing that God strives to create as much being as he can, but that substances are related to one another by their formal natures in such a way that the creation of one substance might per se entail the creation or non-creation of another substance. But this strategy, insofar as it relies on substances being formally or per se dependent upon one another, would clearly contradict the thesis of independence.

The two standard responses to the puzzle of incompossibility offered by Leibniz's commentators have proceeded by effectively abandoning one or another of his three commitments. What has been called the logical approach ${ }^{8}$ to the puzzle of incompossibility insists that not all substances are compossible because at least some substances are related to one another by their formal natures or essences in such way that their co-creation would involve an immediate logical contradiction. ${ }^{9}$ Indeed, in following out this strategy, it has 
typically been suggested that, for Leibniz, each substance must be "world-bound" in such a way that it can, by its essential nature, only be created with all and only its world-mates. ${ }^{10}$ This approach to the problem, of course, preserves well enough the theses of maximization and alternatives since it implies that in creating the best of all possible worlds, God might thereby be precluded from creating other possible worlds on pain of violating the laws of logic. Unfortunately, it would straightforwardly undermine Leibniz's commitment to the thesis of independence since it also implies that every creaturely substance depends per se upon every other creaturely substance with which it is compossible. The logical approach thus does not really show how Leibniz's three theses might be reconciled, but rather suggests abandoning one of them in particular.

What has been called the lawful approach to the puzzle of incompossibility takes a very different tack. It grants that, strictly speaking, all substances for Leibniz are compossible per se, but nonetheless insists that two substances may be incompossible on the hypothesis that they belong to a world governed by suitably harmonious laws. ${ }^{11}$ The intuitive picture here is that God could, without logical contradiction, create any collection of substances, including the limiting cases of any single substance as a "world apart," or all substances together in a maximally inclusive "super-world." Nonetheless, it insists that not all substances are compossible in the sense that not all collections of substances would be suitably harmonious - an incompossibile collection of substances might, for example, fail to intelligibly ground laws of mutual expression, or principles of continuity, or representations of causal, temporal and spatial interaction. ${ }^{12}$ In allowing that substances are not dependent upon one another per se, the lawful approach does better by the thesis of independence than the logical approach, and in suggesting a basis for the partitioning of worlds, it points towards an interesting way of accommodating alternatives. Nonetheless, these gains are accomplished at 
the cost of undermining Leibniz's commitment to maximization since the lawful approach suggests that God fails to create as much being as he can. Thus, at the end of the day, the lawful solution, like the logical solution, does not really show how Leibniz's three commitments might be genuinely reconciled, but rather commends abandoning one of them in particular.

The challenge presented by the puzzle of incompossibility is formidable, and it is tempting to suppose that it cannot be met even in principle - that Leibniz simply must give up at least one of maximization, independence, or alternatives. The aim of the next three sections is to develop three possible lines of response to the puzzle of incompossibility that take advantage of different constraints suggested by Leibniz's own analogies and metaphysical commitments. To anticipate somewhat, the next section will argue that the challenge presented by the puzzle of incompossibility meets its most straightforward response under the constraints implied by Leibniz's own intuitive packing analogies, that is, under the constraints that the world must have a finite volume and be filled with extended corporeal substances. Under those conditions, it is relatively easy to see how Leibniz may hold that no world might contain every possible substance even if no two substances are incompossible per se. The section following the next will then argue that the challenge posed by the puzzle of incompossibility can also be met if the restriction to finite worlds is removed but the assumption of corporeal substances is preserved. Under those circumstances, Leibniz must admit that there is a world containing every possible substance, but he may still deny that that world must be the best of all possible worlds since there may be other "infinite" worlds that not only contain an infinite amount of perfection, but are also more "densely" packed with created being in their local sub-regions. Finally, the last main section takes up the challenge presented by the puzzle of incompossibility with both the restriction to finite 
worlds and the assumption of corporeal substances removed. It will be argued that under those circumstances, the thesis of independence commits Leibniz to the existence of a world containing every possible substance, and the thesis of maximization commits him to identifying that world as the best of all possible worlds. Nonetheless, even allowing that the best of all possible worlds contains every possible substance, Leibniz may still uphold the thesis of alternatives since the compossibility of all possible substances needn't entail the compossibility of all possible worlds, and since in creating the best of all possible worlds God might leave unrealized infinitely many inferior possibilities.

\section{Leibniz's Packing Strategy and Finite Corporeal Worlds}

Although variations on the logical and lawful approaches have long dominated the secondary literature, Leibniz's own response to the puzzle of incompossibility seems to be anchored in an analogy that prima facie suggests a very different strategy. ${ }^{13}$ The analogy - to which Leibniz returns throughout his career - is nicely articulated in a well-known passage from $O n$ the Radical Origination of Things (1697):

$[\Pi \mathrm{t}$ is obvious that of the infinite combinations of possibilities and possible series, the one that exists is the one through which the most essence or possibility is brought into existence. . . the situation is like that in certain games, in which all places on the board are supposed to be filled in accordance with certain rules, where at the end, blocked by certain spaces, you will be forced to leave more places empty than you could have or wanted to, unless you used some trick. There is, however, a certain procedure through which one can most easily fill the board. ... And so, assuming that at some time being is to prevail over nonbeing, or that there is a 
reason why something rather than nothing is to exist, or that something is to pass from possibility to actuality, although nothing beyond this is determined, it follows that there would be as much as there possibly can be, given the capacity of time and space (that is, the capacity of the order of possible existence); in a word, it is just like tiles laid down so as to contain as many as possible in a given area. (G VII 3034/AG 150-1; cf. DM 5/G IV 430; A VI.iv.1396/LOC 239; A VI.iv.1616-17/LOC 305; A VI.iv.1399/LOC 246-7;A.VI.iii.472/LOC 45; G VII 290/RM 9)

Leibniz's geometrical "packing" or "tiling" analogy does little to suggest either the logical or lawful responses to the puzzle of incompossibility that have been favored by his commentators. For in it there is no hint that the existence of one substance might per se entail the existence or non-existence of any other particular substance. Indeed, the analogy might reasonably be read as suggesting just the opposite, for it implies that one collection of tiles might, as a matter of fact and per accidens, preclude another collection of tiles without any one tile per se entailing or excluding any other tile. Nor is there any suggestion that considerations of maximization and order must be traded off against one another as the lawful solution suggests. Indeed, again, just the opposite: in the packing analogy it is the optimal ordering that leads to the inclusion of the most tiles; the peak of harmony and the peak of fecundity are presented as being mutually supportive not mutually exclusive. Thus, echoing the analogy above, Leibniz tells us, "God makes the most things he can and what obliges him to seek simple laws is the need to find a place for as many things as can be put together; if he made use of other laws, it would be like trying to make a building with round stones, which make us lose more space than they occupy" (G I 331/L211; cf. A.VI.iii.58788; G VI 241/H 257). ${ }^{14}$ 
If Leibniz's packing analogy seems to point away from both the logical and lawful approaches to the puzzle of incompossibility, it is less clear what positive solution - or solutions - it might be thought to point towards. As a first step in fleshing out the intuitive strategy of the packing analogy, it should therefore be helpful to see how it might be developed under a pair of simplifying assumptions, namely, that (i) creation involves the realization of extended, corporeal substances, and (ii) is finite in both total volume and number of constituents. The first assumption suggests, of course, that the packing analogy might be taken rather literally, with extended substances spatially excluding one another, and filling up measurable volumes. ${ }^{15}$ The second assumption is intended to hold at bay, for now, complications arising specifically from the possibility of infinite collections, which might be realized either by allowing that the total volume of the world could be infinite, or by granting that extended substances could be either infinitely small or converge through an infinite series to a finite volume. ${ }^{16}$

With both simplifying assumptions in place, it should be clear that two considerations in particular will be relevant in considering whether or not a specific substance is created. The first will be the substance's degree of perfection, or, by the convertibility of the good, its degree of being. We may suppose that, all things considered, God chooses to create substances that are more perfect over substances that are less perfect. In this regard, it is worth noting that one shouldn't imagine that a substance's degree of perfection must be directly proportional to its gross size or volume. For it might easily be the case that a tiny creature may have a much greater amount of perfection than a relatively large creature - a small child, for example, might be far more perfect than an enormous whale. 
The second consideration that will be relevant in considering whether or not a specific substance is created will be what we might call its "packing cost." The packing cost of a substance will be a measure of the extent to which it precludes the existence of other creatures. Again, we may suppose that, all things considered, God chooses to create substances that have a lower packing cost over substances with a higher packing cost. And, in regards to this consideration, it is worth noting that a substance's packing cost likewise needn't be directly proportional to its gross size or volume. For a relatively large creature might fit into a world better than a relatively small creature in much the way that my rain suit packs in my travel bag better than my umbrella even though its gross volume is strictly speaking greater. Furthermore, and relatedly, a substance's packing cost will typically have to be measured relative to a set of substances. For a particular substance might have a high packing cost relative to one set of substances and a low packing cost relative to another set, just as my umbrella packs poorly with my books, but well with my golf clubs. ${ }^{17}$

The considerations of intrinsic perfection and packing cost might, of course, pull in opposite directions. A substance with a higher packing cost might therefore be preferred over a substance with a lower packing cost on the basis of its higher degree of perfection, just as a less perfect creature might be preferred to a more perfect creature because it does less to exclude the existence of other creatures. Thus, Leibniz notes:

Although the more perfect may occasionally be excluded by the more imperfect, nevertheless all in all that way of creating the world is chosen which involves more reality or perfection, and God acts like a first-rate geometer who prefers the best constructions of problems. Thus all beings ... have, in addition to bare possibility, some propensity for existing in proportion to their goodness; and, if God wills it, do exist, unless they are incompatible with more perfect beings, or with a greater 
number of beings. The latter occurs if they have too great a volume in proportion to their potential, so that they occupy more space than they fill, like angular or sinuous things. (A VI.iv.1616-17/LOC 305)

God's decision concerning which possible creatures to actualize thus turns out to be not so different from the more mundane decision one faces in considering what items to take on a trip. In much the way that my decision to pack my umbrella will depend not only on its value to me, but also on what items it would preclude me from packing and their value to me, God's decision concerning whether or not to create a particular substance will take into account not only its intrinsic perfection, but also the implications that the creation of that substance would have with respect to the creation of every other possible substance. The best of all possible worlds will accordingly be the world that instantiates the most efficient packing of substances under the stated constraints; it will be the world that is optimally "stuffed" full of corporeal substances taking into consideration each possible substance's own perfection as well as how it fits together with every other possible substance.

Leibniz's original packing strategy suggests an intuitive - if still preliminary response to the puzzle of incompossility that promises to reconcile all three of its driving commitments. The thesis of maximization will be satisfied as long as there is a uniquely best possible "packing" of creation, and God chooses to instantiate that packing. The former is guaranteed for Leibniz by the fact God chooses to create at all, and the latter by Leibniz's optimism (e.g. DM 22/AG 54-55; Mon 53/AG 220). The thesis of independence may nonetheless be preserved since nothing in the analogy requires the postulation of an illicit per se dependence between any two created substances. Leibniz may hold that, for any two substances $\mathrm{A}$ and $\mathrm{B}$, as far as their formal natures are concerned, A may exist with or without B, and B may exist with or without A (cf. AT VIIIA 18/CSM 1:213). Finally, the 
model of creation presented by the finite packing analogy suggests a straightforward way in which the thesis of alternatives might be maintained. For if not all possible substances can be fitted into a given finite volume, then God will confront different possible ways in which the world might be constituted, with different sets of possible substances representing different solutions to the implicit packing problem. By showing how God might be confronted with such alternatives, the finite packing analogy provides Leibniz with an especially intuitive way to distinguish his own position from the necessitarianism of Spinoza without falling foul of his various other metaphysical and theological commitments.

\section{Leibniz's Packing Strategy and Infinite Corporeal Worlds}

In beginning to work out the strategy implicit in Leibniz's packing analogy, we relied on two important assumptions. The first assumption, concerning Leibniz's commitment to the existence of extended corporeal substances, has become a topic of intense debate among his commentators. Although the issue is far from decided, it now seems likely that Leibniz believed in the existence of extended bodies or substances early in his career, and that it is at least plausible that he continued to be committed to them well into his so-called "middle years" and perhaps even longer. ${ }^{18}$ The second assumption cannot, however, be said to enjoy even such qualified support since Leibniz explicitly embraces the actually infinite, dismissing, for example, Descartes's cautious “indefinite" divisibility of bodies in favor of the view that matter is "really divided by motion into parts that are smaller than any assignable, and therefore actually infinite" and positively affirming that "[t] here is no possible reason, that can limit the quantity of matter; and therefore such limitations can have no place"

(A.VI.iii.214/LOC 25; G VII 374/Alexander 39-40 [section 21]; cf. A.VI.ii.264/LOC 339; G 
III 304-5; G VII 374/Alexander 40 [section 22]). As a next step in fleshing out the strategy of Leibniz's packing analogy, we might therefore consider how it might be applied while maintaining the first simplifying assumption and abandoning the second; that is, we might consider how it might be applied in the context of a metaphysics of infinite worlds composed of extended corporeal substances.

The attempt to extend Leibniz's analogy in this way meets with two principal obstacles. The first concerns how the relative perfection of worlds is to be determined. Once it is allowed that worlds might be infinite, it will no longer do to assume that their relative perfection might be measured by simply summing the perfections of their constituent substances. For, by such a measurement, most infinite worlds might well turn out to have an infinite amount of perfection. ${ }^{19}$ So, for example, assuming that even a starfish has some finite amount of perfection, it might turn out that a world containing nothing but infinitely many starfish will have an infinite amount of perfection, and, indeed, the same amount of perfection as, say, a world containing nothing but infinitely many primates. Measuring the perfection of infinite worlds by simple summation might thus yield not simply an unhelpful, or implausible determination of the relative perfections of worlds, but - what's worse from the perspective of divine choice - the disastrous result that there might be infinitely many equally perfect infinite worlds.

Fortunately, there is an intuitive way of addressing this first obstacle suggested by Leibniz's own insistence on the world's being not merely infinite, but everywhere packed full of organisms within organisms to infinity (e.g. G II 118). For it seems reasonable to suppose that infinite extended worlds should not be compared on the basis of simply summing the perfections of their constituent members, but rather on the basis of something more like their density of perfection. ${ }^{20}$ Thus, for example, an infinite world in which every 
cubic meter sub-region contains, say, ten starfish might be counted as more perfect than an infinite world in which every cubic meter sub-region contains five starfish, even if both contain an infinite number of starfish, and therefore an infinite amount of perfection. Likewise, assuming that primates are intrinsically more perfect than starfish, an infinite world in which every cubic meter sub-region contains ten primates would be counted as more perfect than an infinite world in which every cubic meter sub-region contains ten starfish, even though, again, both worlds might have an infinite total amount of perfection in virtue of containing infinitely many creatures. On this way of determining relative perfection, the best of all possible worlds will be the infinite world with the highest "density" of perfection - the world that has the greatest amount of being "stuffed" into every finite sub-region.

The second obstacle standing in the way of extending the strategy of Leibniz's packing analogy to infinite extended worlds arises from the fact that it now seems plausible if perhaps not quite inescapable ${ }^{21}$ - that there should be a possible world containing every possible finite substance. For, recherché subtleties aside, there should be no difficulty in finding a way to pack every finite extended substance into an infinitely extended creation. If, for example, we imagine that each possible substance is analogous to a finite tile, it should be clear that there will be no difficulty in using every tile in "covering" an infinite twodimensional space. The consequence that God should be able to create a world containing every possible finite substance, however, might be thought to constitute a fatal objection to Leibniz's packing strategy for two distinguishable reasons.

On the one hand, it might be thought that if there were a possible world containing every possible substance it would have to be identical to the best of all possible worlds ( $c f$. A.VI.iii.581-82/DSR 105; A.VI.iv.1651/AG 29). In the context of infinite worlds of extended substances, however, there is no reason to suppose that such a conclusion follows 
since there is no reason to suppose that the world containing every possible substance must have the highest density of perfection as measured above. To see this more clearly, it might be helpful to think once again of possible substances as being analogous to tiles, but now with those tiles coming in two different colors. If there are infinitely many black tiles and infinitely many white tiles, it should be possible to exhaustively tile even an infinite space using either all and only black tiles, or all and only white tiles, or all tiles black and white (following, say, a checkered pattern). If it is assumed that black tiles are more densely perfect than white tiles, it will follow that the exclusively black tiling of the world will be the most perfect, the checkered tiling, representing the world containing every possible substance, will be less perfect, and the exclusively white tiling of the world the least perfect. If worlds are compared in terms of their relative density of perfection, the worry that a world containing every possible substance would have to be identical to the best of all possible worlds simply does not get off the ground.

On the other hand, it might be thought that the very possibility of a world containing every possible substance would undermine Leibniz's rejection of necessitariamism ( $c f$. A.VI.iii.581-82/DSR 105; A.VI.iv.1663-64/AG 100; G III 573/L 662). For it might be imagined that if all possible substances were compossible then all possible worlds would have to be compossible, and that if all possible worlds were compossible, then necessitarianism would become inevitable. (If worlds are composed of substances, and all substances are compossible, how could any two worlds not themselves be compossible?) Again, however, in the context of infinite worlds of extended substances there is a rather straightforward reply to this worry. For in such a context, there is no reason to suppose that the compossibility of all possible substances entails the compossibility of all possible worlds. ${ }^{22}$ To see this more clearly, we might return once again to our analogy of the colored 
tiles. Even granting the possibility of an exhaustive "checkered" tiling of the world containing every possible substance, it does not follow that all tilings of the world must be mutually compatible - indeed, the exhaustive all black, all white, and checkered tilings, for example, are all mutually incompatible. Leibniz could thus admit the possibility of a world containing every possible substance without abandoning his commitment to the thesis of alternatives since such a world would be just one of many mutually incompossible worlds.

Although a little tinkering is required, the move from finite extended worlds to infinite extended worlds does not appear to undermine in any substantial way the intuitive strategy of Leibniz's packing analogy for addressing the puzzle of incompossibility. Even allowing that possible worlds might be constituted by infinitely many extended corporeal substances, Leibniz may still insist that maximization is satisfied as long as God instantiates the most densely perfect infinite world - that is, the infinite world that would realize the most efficient packing of extended corporeal substances. Such an understanding of creation is nonetheless still consistent with his commitment to the per se independence of created substances since it in no way presupposes the sort of formal dependence that is anathema to the traditional view of substance. Finally, Leibniz's commitment to alternatives remains unthreatened, since in choosing to realize one world in particular, God would nonetheless confront infinitely many different, mutually incompatible, possible worlds.

\section{Leibniz's Packing Solution and Infinite Idealist Worlds}

Leibniz's purported shift to an idealist metaphysics - to an ontology of unextended, incorporeal monads - places considerable further pressure on the strategy of his original packing analogy. And in particular, it breathes new life into the two worries raised just 
above arising from the possibility of there being a possible world containing every possible substance. The subsection that follows therefore takes up once again the worry that such a world would have to be identical to the best of all possible worlds, while the subsection following that reconsiders the threat of necessitarianism as it arises from the compossibility of all possible substances. The two subsections taken together will suggest that both worries can indeed be met, but only at the cost of stretching Leibniz's favored packing analogies to the limit and taking on board consequences that Leibniz himself seems clearly bent on rejecting. The conclusion of the essay will suggest two possible lessons that might be drawn from the apparent tension between, on the one hand, Leibniz's favored strategy for responding to the puzzle of incompossibility, and, on the one hand, his alleged embrace of a thoroughgoing idealism on the other. ${ }^{23}$

\subsection{Must the Best World Contain Every Possible Substance?}

In light of his commitment to the per se independence of created substances, it seems that in an idealist setting Leibniz must once again grant that there is a possible world containing every possible substance. And so we must ask once again if that world must be identical to the best of all possible worlds.

Earlier we were able to answer negatively by arguing that in the context of his metaphysics of extended substances, it made sense to compare the relative perfection of infinite worlds by looking at how densely they were packed with being in every finite region, and noting that, on such a standard, there is no reason to suppose that the world containing every possible substance must be the best. In the context of Leibniz's purported idealism, however, that response is no longer adequate: if substances are no longer extended spatially, 
it will no longer make sense to consider how densely they are packed. ${ }^{24}$ For to the extent that the notion of density remains well-defined in such a context, all infinite worlds, it would seem, should be reckoned infinitely dense with perfection and thus all equally perfect. Nor will the simple summation formula originally suggested by the finite packing analogy be of any help. For that formula will still yield the result that all infinite worlds - all worlds containing infinitely many substances - should be infinitely, and thus equally, perfect.

An answer to our question as to whether the best world must contain every possible substance thus turns out once again to presuppose an appropriate standard for determining the relative perfections of worlds. And here we might take as a guiding idea the thought that one world is more perfect than another world just as long as it contains all of the other world's perfections and the other world does not contain all of its perfections. That is, $\mathrm{W}_{1}$ is better than $\mathrm{W}_{2}$, if $\mathrm{W}_{1}$ contains all the perfections of $\mathrm{W}_{2}$, but $\mathrm{W}_{2}$ does not contain all the perfections of $\mathrm{W}_{1}$.

While such a notion will not provide us with a completely general rule for comparing any two worlds (since, prima facie, $\mathrm{W}_{1}$ might lack some perfections of $\mathrm{W}_{2}$, while $\mathrm{W}_{2}$ lacks some perfections of $\mathrm{W}_{1}$ ), it does suggest that our leading question must be answered affirmatively (that is, that the best world must indeed contain every possible substance). For, assuming that all of a world's perfections must ultimately be grounded in its constituent substances, it implies that if $\mathrm{W}_{1}$ contains all the substances of $\mathrm{W}_{2}$, and $\mathrm{W}_{2}$ does not contain all the substances of $\mathrm{W}_{1}$, then $\mathrm{W}_{1}$ must be more perfect than $\mathrm{W}_{2}$. But from that it follows that if all possible substances are compossible then the best of all possible worlds must contain every possible substance. For if the best of all possible worlds did not contain every possible substance, then there would be another world that contains all the substances of the best world and then some, and thus there would be a world that contains all the perfections 
of the best world and then some, and thus - per impossible - there would be a world better than the best of all possible worlds. Given such a standard for comparing possible worlds, it thus seems inescapable that the best world must contain every possible substance, and, by implication, that the actual world must contain every possible substance.

This is an initially surprising result that Leibniz - while he is not entirely unequivocal on the point - appears to reject solidly (see, e.g. NE III.vi.307; A VI.iv.1653-54/AG 94; but see also, G III 572/L 661). Although we'll return later to the question of what to make of Leibniz's denial of what appears to be a fairly obvious consequence of his packing strategy, for now it may be most helpful to focus on the question of whether or not the consequence that the best of all possible worlds must contain every possible substance constitutes a fatal objection to the packing strategy as applied in the context of an idealist metaphysics. A closer look at two worries that might be thought to flow from that consequence suggests that it does not.

The first such worry, naturally, concerns the apparent ontological extravagance of supposing that the actual world must contain every possible substance. If the actual world were to contain every possible substance, Leibniz might seem to be committed to the existence of (say) talking donkeys, doppelgangers, and what we would have thought were fictional characters. Such a consequence, put frankly, might well seem simply absurd - too great a violation of metaphysical parsimony to be countenanced.

It is tempting to respond to this worry by pointing out ways in which the ontological extravagance in question might be played down. For one, it might be noted that the extravagance here is restricted to genuinely possible substances. Leibniz thus needn't, for example, allow that the actual world contains every possible chair, desk or laptop computer since such objects will not, for him, meet the demands required of substances. Indeed, if 
Leibniz is read as a thoroughgoing idealist, the notion of substance would seem to be stringent enough to yield the result that the actual world contains no physical objects at all. Thus, although Leibniz's embrace of the result that the actual world contains every possible substance would make his ontology very generous along one dimension, it would nonetheless still be quite austere along other dimensions. For another, it might be noted that, if one reads Leibniz as a moderate essentialist - that is, as holding the view that created substances do not have all of their intrinsic properties essentially - the result that the actual world contains all possible substances will not entail the further consequence that the actual world contains all genuinely possible ways of being. ${ }^{25}$ For consistent with a moderate essentialism, Leibniz could maintain that the best of all possible worlds must contain (say) Caesar, since he is a possible substance, but it needn't realize the possibility of (say) Caesar's willing to cross the Rubicon, or desiring unfettered power. Each substance might, on such a reading, thus be thought of as like a determinable that might be created in infinitely many different determinate ways. In creating the best of all possible worlds, God would be committed to creating all determinables, but not all determinates, and thus would be committed to realizing all possible substances, but not all possible ways of being. Indeed, more strongly, since many of a substance's ways of being will be mutually inconsistent - just as many determinates of a given determinable will be mutually inconsistent - God will be positively precluded from creating every possible way of being even while being morally constrained to create every possible substance.

But while such maneuvers might go some distance towards salving contemporary scruples concerning ontological parsimony, it is far from clear that Leibniz would - or should - agree that there is really any difficulty here to begin with. For, as has already been suggested, Leibniz's metaphysics in general inclines towards ontological fecundity rather 
than parsimony, and, indeed, Leibniz himself explicitly embraces the view that there is a presumption in favor of something's existing rather than not existing (A.VI.iii.472/DSR 212). Given his commitment to emphasizing the fullness and richness of creation, it is not clear why Leibniz, at least, should be especially troubled by the supposed ontological "extravagance" of the result that the actual world contains every genuinely possible substance. The first worry, or apparent worry, thus does not, at the very least, appear to decisively undermine Leibniz's packing strategy as applied in the context of an idealist metaphysics.

A second worry, more serious from Leibniz's perspective, concerns an apparent implication for divine justice that might seem to follow from the actual world's containing every possible substance. In a short piece that has appropriately enough been entitled $M y$ Principle is: Whatever Can Exist and is Compatible with Others, Exists, Leibniz states the worry for himself:

[1] can be shown that not all things which are possible per se can exist together with other things. For otherwise there will be ... evil and miserable minds, and also injustices, and there would be no reason why God should be called good rather than evil, and just rather than unjust. There could be some world in which all good people are punished with eternal penalties, and all evil people would be rewarded, and would expiate crime with happiness. ... If all possibles were to exist ... a God of the kind in whom the pious believe would not be possible. (A.VI.iii.581-82/DSR 105; cf. G IV 283-4/L 273)

The deep difficulty highlighted in this passage is the thought that if God were to create every possible substance, he would thereby create, for example, virtuous people unjustly punished, and wicked people unjustly rewarded. In that case, however, it would seem that any basis 
for calling God himself just would be undermined, unless one retreated to the view - which Leibniz explicitly rejects ${ }^{26}$ - that God's will determines what is just rather than what is just determining God's will.

Although the worry here clearly plays a role in Leibniz's own thinking about incompossibility, like its predecessor, it does not, I think, represent a fatal difficulty for his packing strategy as applied in an idealist context. For either the notion of a possible creature essentially punished unjustly by God is incoherent, or it is not. If, on the one hand, it is incoherent, the present worry presents no real difficulty for Leibniz. For if one maintains and I think this is Leibniz's best option - that, for example, creatures are only inessentially punished by God, or that it is literally impossible for God to unjustly punish beings that owe their entire existence to him, ${ }^{27}$ then the creation of every genuinely possible substance simply will not entail the consequence that God punishes some creatures unjustly. If, on the other hand, the notion of a creature essentially punished unjustly by God is coherent, then the doctrine of the convertability of the good will entail that God should nonetheless instantiate such possible beings. (And, indeed, the dark side of the doctrine of the convertability of the good has always been that, according to it, there is no genuinely possible existence so wretched, miserable, or unfair that is worse than not existing at all. ${ }^{28}$ ) If that is a nonintuitive, or problematic consequence, it is, at any rate, a consequence not of Leibniz's packing analogy - or even of the conclusion that God must create every possible substance but rather of the traditional identification of goodness and being when taken together with the insistence that there are some creatures that can only exist if they are unjustly punished by God. Thus the second worry, although it raises somewhat deeper issues for Leibniz and clearly plays a role in his thinking about the puzzle of incompossibility, does not, for all that, 
seem to represent a fatal objection to the packing strategy per se as applied in an idealist context.

It thus appears that Leibniz could have embraced the consequence that the best of all possible worlds contains every possible substance without doing any real damage to his larger philosophical system, and, in doing so, simply stared down one potential line of objection to extending his packing solution to a thoroughly idealist metaphysics.

\subsection{Does the Compossibility of All Possible Substances Entail Necessitarianism?}

It was suggested above that, in the context of his metaphysics of extended corporeal substances, Leibniz could deny that the compossibility of all possible substances entails the compossibility of all possible worlds since the creation of one infinite collection of extended substances might physically preclude the creation of another infinite collection of extended substances. The appeal to physical exclusion made in that argument, however, will of course no longer do in the context of a thoroughly idealist metaphysics. And so we must ask once again, now in an idealist setting, if the compossibility of all possible substances entails the compossibility of all possible worlds. And, to the extent that it does, whether the compossibility of all possible worlds entails necessitarianism.

How one answers the first question - does the compossibility of all possible substances entail that all possible worlds are compossible? - will depend in part on whether one reads Leibniz as a moderate or strong essentialist. ${ }^{29}$

On a moderate essentialist reading, Leibniz could insist that while all possible substances are compossible, not all possible worlds are compossible on pain of God having to create a substance that is not identical to itself. For, to return to our earlier example, on 
the moderate essentialist view, Caesar could will or not will to cross the Rubicon, desire or not desire unfettered power, and so on. There should thus be, among all the possible worlds, a possible world in which Caesar wills to cross the Rubicon, and a possible world in which Caesar does not will to cross the Rubicon. Are these two worlds compossible? It seems that they must not be on pain of God creating something that both wills and does not will to cross the Rubicon, or, to put the same point in different terms, on pain of God creating Caesar not identical to himself. On one understanding of Leibniz's essentialism, he thus has a quick reply not only to the first question (does the compossibility of all possible substances entails the compossibility of all possible worlds) but also to its follow up: given a moderate essentialism, not all possible worlds are compossible, and the apparent threat of necessitarianism doesn’t even arise (since God must still choose between many mutually incompatible worlds).

On a strong reading of Leibniz's essentialism - that is, on a reading according to which substances have all of their intrinsic properties essentially - how we answer the question "Does the compossibility of all possible substances entail that all possible worlds are compossible?” will turn on the further question of how one understands the individuation of created worlds. ${ }^{30}$

On one intuitive way of individuating created worlds - let's call it the "parsimonious way" - a created world will be defined by the most inclusive set of created substances. So, for example, if God were to create only three substances, say, Caesar, Crassus, and Pompey, he would be understood to have created only one world, namely, the world defined by the set $\{$ Caesar, Crassus, Pompey\}. If one individuates created worlds in this way, the incompossibility of possible worlds will follow trivially even given the compossibility of all possible substances. To see this more clearly, consider two possible worlds $W 1=\{A, B\}$ 
and $\mathrm{W} 2=\{\mathrm{A}\}$ (where W1 might be, for example, the world containing every possible substance, and W2 the world containing every possible substance minus Caesar). Are these two worlds compossible, that is, could God instantiate both of them together? On a parsimonious way of individuating worlds, the answer must be no. For if God were to create A and B, he would instantiate W1, but not W2. If he were to create A alone he would instantiate W2 but not W1. (And even if he were to create, in violation of the identity of indiscernibles A, B and A, he would still instantiate a distinct world, $W 3=\{\mathrm{A}, \mathrm{B}, \mathrm{A}\}$ and thus neither W1 nor W2.) On a parsimonious way of individuating created worlds, the incompossibility of possible worlds falls out trivially even assuming the compossibility of all possible substances and a strong reading of Leibniz's essentialism.

On a perhaps less intuitive way of individuating created worlds - let's call it the "non-parsimonious way" - a created world might be defined by any subset of created substances. $^{31}$ On this way of individuating worlds, if God were to create only Caesar, Crassus, and Pompey, he could be understood to have created at least seven worlds defined by the sets $\{$ Caesar, Crassus, Pompey $\},\{$ Caesar, Crassus $\},\{$ Crassus, Pompey $\},\{$ Caesar, Pompey $\},\{$ Caesar $\},\{$ Crassus $\},\{$ Pompey $\}$. If one individuates created worlds in this way, the compossibility of all possible substances will indeed entail the compossibility of all possible worlds. For on such a way of individuating created worlds, it will follow trivially that if God were to instantiate the world containing every possible substance, he would thereby also instantiate the world containing every possible substance minus Caesar, the world containing every possible substance minus Caesar and Crassus, etc. Given a nonparsimonious approach to individuating worlds, an affirmative answer to our first question (Does the compossibility of all possible substances entail the compossibility of all possible worlds?) must follow straightaway assuming a strong reading of Leibniz’s essentialism. 
Now, however, we must ask in earnest our second question: does the compossibility of all possible worlds, counted in a non-parsimonious way, commit Leibniz to necessitarianism? And the answer, perhaps somewhat surprisingly, is, I think, quite clearly, "no." For the relevant threat of necessitarianism is rooted in the idea that if God were to create every possible world, then there would be no sense in which he could have created otherwise - that he would be not just morally, but logically, locked into creating the actual world assuming that he creates at all. But on the non-parsimonious way of individuating worlds, that conclusion does not follow since at the moment of creation God still confronts infinitely many metaphysically and morally distinct alternatives. He could, for example, create all the possible worlds together constituted by all the possible substances, or, instead, he could create (only) all the possible worlds constituted by all the possible substances minus Caesar, or, instead again, all the possible worlds constituted by all the possible substances minus Caesar and Crassus, etc. In short, even on a maximally permissive way of individuating possible worlds, the thesis of alternatives would still be preserved given that God is not logically required to create all possible substances and thereby all possible worlds. ${ }^{32}$

It thus appears that Leibniz could have embraced the consequence that the best of all possible worlds contains every possible substance and still avoided, by any of several different routes, the specter of a Spinozistic necessitarianism.

\section{Conclusion}

In spite of the attention that has been devoted to developing the so-called logical and lawful approaches to the puzzle of incompossibilty, Leibniz's packing strategy offers his most considered and most promising approach for fully addressing the difficulties that the puzzle 
presents. That strategy is easiest to follow out in the simplified context of finite corporeal substance worlds where it is especially easy to see how the creation of one set of substances might preclude the existence of another set of substances without assuming that all of a world's substances are formally co-dependent, or that God creates under the constraint of realizing some set or other of harmionous laws. With a few relatively minor and intuitive adjustments, however, the strategy suggested by Leibniz's packing analogies may also straightforwardly be applied in the context of an infinite metaphysics of extended corporeal substances. In such a context, the assumption that there is no possible world containing every possible substance must be abandoned, but Leibniz could still insist that the best of all possible worlds needn't contain every possible substance, and that the existence of one infinite world might physically preclude the existence of another infinite world. Finally, with considerably more effort and strain, Leibniz's packing strategy might even be applied in the context of a thoroughly idealist metaphysics of the sort that Leibniz is widely thought to have embraced in his mature writings.

Having argued that Leibniz's packing strategy provides him with the resources for solving the puzzle of incompossibility in both non-idealist and idealist contexts, it should nonetheless be granted that the move from the former to the latter stretches Leibniz's favored analogies of arranged tiles and stacked stones to the breaking point. Furthermore, it should be acknowledged that the move from worlds that include corporeal substances or extended bodies to worlds containing only mind-like monads raises some fairly obvious concerns that Leibniz shows no sign of solving, or even addressing, for himself. In light of the persistence of his packing analogies - paradigmatic examples range from at least On the Secrets of the Sublime in 1676 to On the Radical Origination of Things in 1697 - this neglect on 
Leibniz's part would seem to leave us with two very different possible pictures concerning the historical development of his thinking about the puzzle of incompossiblity.

According to the first picture, Leibniz's thinking about the puzzle is fixed in the context of his early metaphysics of extended corporeal substances, where it finds its most intuitive home, and is carried over, apparently without much reflection, to his later metaphysics of unextended incorporeal substances where it confronts new and difficult challenges that seem to have escaped his attention. According to this picture Leibniz's failure to retool his solution to the puzzle of incompossibility in order to fit the demands of a thoroughgoing idealism would be attributed to simple neglect - a not entirely implausible suggestion given the massive demands on Leibniz's time especially towards the end of his career.

According to the second picture, Leibniz's thinking about the puzzle of incompossibility is still fixed in the context of his early metaphysics of extended corporeal substances, but goes unchanged because he continues to hold onto the possibility that the created world contains not only immaterial minds but also extended corporeal substances or bodies. That is, Leibniz fails to reconsider the implications of his packing strategy because its metaphysical foundations remain largely unchanged relatively late into his career. Insofar as it attributes to Leibniz a consistent, well-reasoned, even intuitive response to the puzzle of incompossibility, such a picture would seem to offer a more charitable understanding of his philosophical development, and might well provide a new line of attack for those commentators who see more than vestiges of extended corporeal substances or bodies in his "middle years" and beyond. ${ }^{33}$ 
${ }^{1}$ Strictly speaking, possible worlds, for Leibniz, are concepts in the divine intellect and, as such, are as uncreated as God himself. For ease of expression, however, I will sometimes speak of "God's creating a possible world” by which I will mean “God's bringing into existence a world in accordance with the concept of some possible world." I will similarly use the expression "God's creating a possible substance" to mean more strictly "God's creating a substance in accordance with a complete concept of a possible substance.” ${ }^{2}$ See, for example, A VI.iv.1384-5/AG 281-2; A VI.iv.1653/AG 94; and G VI 217-18/H 234-36. I will use the following abbreviations for Leibniz's texts: A = Deutsche Akademie der Wissenschaften, ed., Gottfried Wilhelm Leibniz: Sämtliche Schriften und Briefe (Darmstadt and Berlin: Akademie-Verlag, 1923-), cited by series, volume, and page; AG = R. Ariew and D. Garber, ed. and trans., Philosophical Essays (Indianapolis: Hackett, 1989); Alexander = H. G. Alexander, ed., The Leibniz-Clark Correspondence (Manchester: Manchester University Press, 1956); DSR = G. H. R. Parkinson, ed. and trans., De Summa Rerum: Metaphysical Papers, 1675 1676 (New Haven: Yale University Press, 1992); G = C. I. Gerhardt, ed., Die Philosophische Schriften von Gottfried Wilhelm Leibniz (Berlin: Weidmann, 1875-90; repr. Hildesheim: Olms, 1960), cited by volume and page; $H=$ E. M. Huggard, trans., Theodicy (LaSalle: Open Court, 1985), reference is to section number; L = L. E. Loemker, ed. and trans., Philosophical Papers and Letters 2 nd edition (Dordrecht: Reidel, 1969); LDB = Brandon C. Look and Donald Rutherford, ed. and trans., The Leibniz-Des Bosses Correspondence (New Haven: Yale University Press, 2007); LOC = R. T. W. Arthur, ed. and trans., The Labyrinth of the Continum: Writings on the Continuum Problem, 1672-1686 (New Haven: Yale University Press, 2001); RM = Mary Morris and G. H. R. Parkinson, ed. and trans., A Résumé of Metaphysics (London: J M Dent and Sons Ltd, 1973), 145-147, cited by section number. NE = P. Remnant and J. Bennett, 
ed and trans., New Essays on Human Understanding (Cambridge: Cambridge University Press 1996) reference is to book, chapter, section. I will also use the following abbreviations for Descartes's works: AT $=$ C. Adam and P. Tannery, eds., Oeuvres des Descartes, 12 Volumes (Paris: J. Vrin, 1964-76) reference to volume and page; CSM = J. Cottingham, R. Stoothoff, and D. Murdoch, eds. and trans., The Philosophical Writings of Descartes, Volumes 1 and 2 (Cambridge: Cambridge University Press, 1985) reference is to volume and page.

${ }^{3}$ Thus, Leibniz: “. . . God is absolutely perfect - perfection being nothing but the magnitude of positive reality considered as such ...” (G VI 614/AG 218), and "There exists, therefore, that which is the most perfect, since perfection is simply quantity of reality" (G VII 290/RM 11). For discussion and texts concerning the historical roots of the doctrine of the convertibility of the good, see Scott MacDonald, ed., Being and Goodness (Ithaca NY: Cornell University Press, 1991).

${ }^{4}$ See, for example, Francisco Suarez, Disputationes Metaphysicae (Salamanca, 1957), Disputation XXXIII, Sections 1 and 3. The notion that substances are per se independent has its roots, of course, in the Aristotelian tradition. See, for example, Aristotle, Categories in Categories and De Interpretatione, trans., J. L. Ackrill (Oxford: Clarendon Press, 1963), Chapter 5, 2¹0-13; and Metaphysics in The Complete Works of Aristotle, Volume II, trans., W. D. Ross (Princeton: Princeton University Press, 1984), Book V, Chapter 8; Thomas Aquinas, Quaestiones disputatae, ed. Raymund M. Spiazzi (Rome: Marietti, 1964-1965), Book III, Question 9, Article 1, contra.

${ }^{5}$ Jorge Gracia, "Glossary," in Francisco Suarez,on Individuation, Metaphysical Disputation V: Individual Unity and Its Principle (Milwaukee, Wisconsin: Marquette University Press, 1982), 267-9. 
${ }^{6}$ What to say about the dependence of creatures upon God was a matter of somewhat greater controversy and complexity. For two different approaches, see Thomas Aquinas, Summa contra Gentiles, trans. Anton C. Pegis et al. (Notre Dame, IN: University of Notre Dame Press, 1975), Book I, Chapter 25; and Descartes, AT VIIIA 24/CSM 1:210 and AT VII 170/CSM 2:120.

${ }^{7}$ How each of these theses - including the "world-apart thesis" - is ultimately to be interpreted is, of course, a matter of considerable controversy. For a stimulating entry point into the literature, see J. A. Cover and John O'Leary Hawthorne, Substance and Individuation in Leibniz (Cambridge: Cambridge University Press, 1999).

${ }^{8}$ The distinction between "logical" and "lawful" approaches to the puzzle of incompossibility goes back to Fred D'Agostino, "Leibniz on Compossibility and Relational Predicates," in Leibniz: Metaphysics and Philosophy of Science, ed. Roger Woolhouse (Oxford: Oxford University Press, 1981), 89-103. I, however, follow Margaret Wilson’s proposed terminology, opposing "logical" to "lawful" approaches, rather than D'Agostino's which opposes "analytic" to "synthetic" approaches. See, her "Compossibility and Law," in Causation in Early Modern Philosophy, ed. Steven Nadler (University Park: Pennsylvania State University Press, 1993), 119-33.

${ }^{9}$ For development of the logical approach, see Jaakko Hintikka, "Leibniz on Plentitude, Relations, and the 'Reign of Law',' in Harry G. Frankfurt, ed., Leibniz: A Collection of Critical Essays (Garden City, NY: Doubleday, 1972), 155-190; Benson Mates, “Leibniz on Possible Worlds," in Leibniæ: A Collection of Critical Essays, 335-64 and The Philosophy of Leibniz: Metaphysics and Philosophy of Language [The Philosophy of Leibniz] (New York: Oxford University Press, 1986), 76-8; Nicholas Rescher, Leibniz: An Introduction to His Philosophy [Leibniz] 
(Lanham, MD: University Press of America, 1979). Margaret Wilson, "Compossibility and Law," develops something of a hybrid approach defending a logical solution, by arguing that it can effectively accommodate the strategy of the lawful solution.

${ }^{10}$ Hence Rescher: "No substance can - even in hypothesis - be pried loose from its worldenvironment and transposed into some other possible world. No possible substance can populate two distinct possible worlds, and no member of one world can be compatibly united with any member of any other," Leibniz, 50. Cf. Mates, The Pbilosophy of Leibniz, 44 and 77 .

${ }^{11}$ For development of the lawful approach, see Bertrand Russell, A Critical Exposition of the Philosophy of Leibniz, $2^{\text {nd }}$ edition (London: George Allen and Unwin, 1937; reprinted London: Routledge, 1997) 66-7; Ian Hacking, “A Leibnizian Theory of Truth,” in Michael Hooker, ed., Leibniz: Critical and Interpretative Essays (Minneapolis: University of Minnesota Press, 1982), 185-95; Gregory Brown, "Compossibility, Harmony, and Perfection in Leibniz," Philosophical Review 96 (1987): 172-203; Jan Cover and John O’Leary-Hawthorne, Substance and Individuation in Leibniz (Cambridge: Cambridge University Press, 1999), 131-141. See also, Wilson, "Compossibility and Law," 126-33. It is worth noting that the qualification that the laws must be "suitably harmonious" is crucially important here since Leibniz implies that any collection of substances would instantiate some laws or other; see, for example, DM 6, and G VII 312/MP 78-9.

${ }^{12}$ In something of a twist on this strategy, it has more recently been suggested that some such conditions should be viewed as necessary for the creation of something that could be called a "world," and thus that not all substances are compossible for Leibniz on pain of God's creating merely a collection of substances rather than a single world. See, Donald 
Rutherford, Leibniz and the Rational Order of Nature (New York: Cambridge University Press, 1995), 181-88; Olli Koistinen and Arto Repo, "Compossibility and Being in the Same World in Leibniz's Metaphysics," Studia Leibnitiana 33 (1999): 196-214; James Messina and Donald Rutherford, "Leibniz on Compossibility," Philosophy Compass 4:1 (2009): 1-16. Although this approach raises a host of interesting questions, and suggests some intriguing connections to the Kantian tradition, it still leaves unanswered the question, "Why doesn't God realize other possible substances?" whether that question is posed as "Why doesn't God create other worlds as well as the actual world?" or "Why does God realize a world instead of some more inclusive creation?" Cf. J. A. Cover and John O'Leary-Hawthorne, Substance and Individuation in Leibniz, (Cambridge: Cambridge University Press, 1999), 140.

${ }^{13}$ An exception to this general trend can be found in Catherine Wilson, "Plentitude and Compossibility in Leibniz," Leibniz Review 10 (2000): 1-20.

${ }^{14}$ For an illuminating discussion of this point, see David Blumenfeld, "Perfection and Happiness in the Best Possible World," in Nicholas Jolley, ed., The Cambridge Companion to Leibniz (Cambridge: Cambridge University Press, 1995), 382-410.

${ }^{15}$ Cf. Leibniz's remark that " [] t does not seem possible for all possible things to exist, since they get in each other's way" (A.VI.iv.1651/AG 29). One might, of course, wonder what sort of impossibility exactly is at stake here; that is, in what sense does the presence of one body in a given place preclude the existence of another distinct body in the same place? Leibniz's criticisms of Descartes and Locke suggest that he might not want to construe the relevant modality as strictly logical in force (see, for example, NE II.iv). It is probably best therefore to think of the relevant modality as involving a natural, or non-miraculous impossibility grounded in the solidity (or more fundamentally the passive powers) of bodies. 
It is worth noting that such a modality, while weaker than a logical modality, would nonetheless be stronger than the modality typically suggested by proponents of the lawful solution since it would seem that a substance might unfold in accordance with its own powers - and thus naturally, non-miraculously - and yet still not be in harmony with the rest of creation. That is, if one understands miracles in "the philosophical sense of what exceeds the powers of created things," it would seem that spatial collocation of solid bodies would have to be miraculous, but mere "disharmony," grounded in the natural unfolding of created substances, needn't be miraculous (G IV 520/L 494; cf. T 207/G VI 240-41).

${ }^{16}$ The restriction of creation to a finite volume might, of course, be satisfied by supposing that God must create substances within the finite bounds of an independently existing spacetime structure. No particular view on the foundational nature of space or time, however, need be presupposed. The restriction will remain equally intelligible, for example, even on the supposition that space supervenes on the intrinsic extension and arrangement of extended substances.

${ }^{17}$ Interestingly, in a number of early texts, Leibniz at least toys with the idea that the physical world must be filled with spheres since (as he supposes) they would allow for the most efficient packing of the world. Thus, for example, in an early piece, tentatively dated to 1676, and entitled, On the Plentitude of the World, Leibniz writes, "A wonderful plenum of the kind that I expound is rational, even though it consists in nothing but spheres. For there is no place so small that there cannot be assumed to exist in it a sphere which is less than it. Assuming that things are so, there will be no assignable place that is empty" (A.IV.iii.525/DSR 87; cf. A.VI.iv.1399/LOC 247; A VI.ii.284, lines 15-20). 
${ }^{18}$ For an entry point into the debate, see especially, Robert Adams, Leibniz: Determinist, Theist, Idealist (Oxford: Oxford University Press, 1994); Daniel Garber, "Leibniz and the Foundations of Physics: The Middle Years," in K. Okruhlik and R. Brown, eds., The Natural Philosophy of Leibniz (Dordrecht: D. Reidel, 1985), 27-130; Glenn Hartz, Leibniz's Final System (New York: Routledge, 2007); Pauline Phemister, Leibniz and the Natural World (Dordrecht: Springer, 2005); Peter Lopston and Richard Arthur, "Leibniz's Body Realism,” The Leibniz Review 16 (2005): 1-42; Donald Rutherford, "Leibniz as Idealist," Oxford Studies in Early Modern Pbilosophy, 4 (2008): 141-190.

${ }^{19}$ It is, of course, possible that even an infinite world might have a finite amount of perfection, that is to say, the perfections of an infinite world's constituent substances might nonetheless converge to a finite sum. If all infinite worlds were "convergent" worlds in this sense, infinite worlds could be treated in essentially the same manner as finite worlds, and we'd be done. Not wishing to rest the argument on such an assumption, in what follows I'll assume that this way of handling infinite worlds is not available.

${ }^{20}$ It would, of course, be exceedingly difficult - perhaps impossible - to make this notion both fully general and rigorous. And, indeed, it might be the case that the best we could do in that direction would be to lay down a series of sufficient conditions for one world's being more densely packed than another. Fortunately, for our purposes, the intuitive idea by itself should suffice. It is perhaps worth underscoring, however, that on the present reading world-density should not be seen as an additional "aesthetic" constraint to be weighed against a world's containing more reality than it would otherwise (as so-called "lawful" readings might suggest). Rather the notion of world-density, as it is used here, should be thought of as helping to explicate what it means for one infinite world to have more reality 
than another, especially in light of the fact that many infinite worlds may have the same amount of perfection when judged by a simple summation formula.

${ }^{21}$ One might attempt to resist this conclusion, for example, by drawing on cardinality results most familiar from contemporary set theory as well as Leibniz's combinatorialist tendencies not only with respect to substances but also with respect to their properties. Although such an attempt, if successful, would offer a short response to the present objection (and thus make the task of the present section that much easier) I think Leibniz's packing strategy can be defended without appealing to such subtleties. Those interested in such issues, however, should see Catherine Wilson, "Plentitude and Compossibilty," 16-18; as well as the debate over Leibniz's views on the possibility of infinite wholes as discussed in Laurence Carlin, "Infinite Accumulations and Pantheistic Implications: Leibniz and the "Anima Mundi," Leibniz Society Review 7 (1997): 1-24; Gregory Brown, “Who’s Afraid of Infinite Numbers? Leibniz and the World Soul," Leibniz Society Review 8 (1998): 113-125; and "Leibniz on Infinite Wholes, Unities, and Infinite Numbers," The Leibniz Review (10) 2000: 21-50; and Richard Arthur, "Infinite Number and the World Soul: In Defense of Carlin and Leibniz," The Leibniz Review 9 (1999): 105-116.

${ }^{22}$ One might, perhaps, attempt to defend this inference by appealing to certain readings of Leibniz's views on relations. It is worth noting therefore that if Leibniz were to grant the inference, he could still ground his rejection of necessitarianism in one of the argumentative strategies sketched in section 4.2. below.

${ }^{23}$ Although the solutions of the present section will necessarily differ in important ways from the solutions of previous sections, they may nonetheless be thought to be continuous with those solutions in at least two important respects. First, the solutions here may be 
thought of as extending the solutions of the previous section to the limiting case in which the volume of every possible substance is zero. Second, the solutions here are developed under the same core constraints as the solutions of the previous two sections, that is, under the constraints that there are no per se inclusion or exclusion relations between distinct substances, and that God does not sacrifice the goal of maximizing created being for the sake of something like beauty or harmony. In these respects, the solutions of the present section, like the solutions of previous sections, stand in contrast with both "logical" and "lawful" accounts of Leibniz's response to the puzzle of incompossibility.

${ }^{24}$ One might be tempted to suppose that the density of an incorporeal world might be measured by the density of the phenomenal world "projected" by its respective substances. The difficulty with such a suggestion is that it must presuppose that all of the incorporeal substances constituting a world (or if the term "world" is loaded, a possible creation) must project a single phenomenal world (cf. Leibniz's intriguing remarks at A.VI.iii.512/DSR 6567). But asking, "why must all the incorporeal substances constituting a world project a single phenomenal world?" would simply take us back to where we started. For if the "must" is given logical force, it is prima facie inconsistent with the thesis of independence, and if it is given moral force, it is prima facie inconsistent with the thesis of maximization.

${ }^{25}$ For a classic discussion and defense of such a reading, see R. C. Sleigh, Jr., Leibniz and Arnauld: A Commentary on Their Correspondence (New Haven: Yale University Press, 1990), 4894. ${ }^{26}$ See, for example, A.VI.iv.1389.lines 21-25; A.VI.iv.1385-85/AG 282; G IV 283-4/L 273. 
${ }^{27}$ St. Augustine, for example, suggests such a view in his Ad Simplicianum de Diversis

Quaestionibus, 2 Books in J. P. Migne, ed., Patria Cursus Completus, Series Latina (Paris: 1844-55, volume 40, pages 101-48), book 1, chapter 2, paragraph 16.

${ }^{28}$ Compare, for example, St. Augustine's treatment of suicide in his De libero arbitrio voluntatis, in W. M. Green, ed., Corpus Christianorum: Series Latina, volume 29 (Turnhout, Belgium: Brepols, 1970; available in English translation in Thomas Williams, Augustine: On Free Choice of Will (Indianapolis, IN: Hackett Publishing Company, 1993), $83 \mathrm{f}$.

${ }^{29}$ In order to keep the main points in focus, I set aside here readings of Leibniz as a "superessentialist," that is, readings according to which Leibniz insists on a substance's having all of its properties - extrinsic as well as intrinsic - essentially. It is perhaps worth noting, however, that it is at any rate difficult to see how such a reading of Leibniz's essentialism might be genuinely squared with his commitment to the thesis of independence.

${ }^{30}$ For a discussion and defense of a strong reading of Leibniz's essentialism, see J. A. Cover and John O'Leary-Hawthorne, Substance and Individuation in Leibniz (Cambridge: Cambridge University Press, 1999), 87-142.

${ }^{31}$ It is worth noting that this way of individuating created worlds would appear to contradict Leibniz's explicit rejection of the thesis - notorious in his own era - of the plurality actual worlds. See, for example, GP VI 107/H 128.

${ }^{32}$ One might reasonably wonder why, if this rather curt response to the threat of necessitarianism is available to Leibniz, he bothered developing more subtle accounts of divine choice at all. The short answer is, I think, that Leibniz is as much, or indeed more, concerned to show that God's choosing to create the actual world is suitably providential as that it is contingent. Indeed, although Leibniz appears to have been initially attracted to 
Spinoza's necessitarianism, he never seems to have been tempted by Spinoza's rejection of divine teleology (A VI.iv.1653, A VI.iv.1710, A VI.iii.364; cf. Spinoza, Ethics, ed. and trans. Edwin Curley (Princeton, NJ: Princeton University Press, 1985), [Appendix to Part I] 439446. Leibniz might therefore have found, for example, the suggestion that, even if there were only one possible world, God could choose to either create or not to create that world sufficient to rebut necessitarianism, but insufficient for securing a suitable form of divine providence. For further discussion of the relationship between Leibniz's views on divine contingency and divine providence see Daniel Garber, Enchanting the World: Leibniz on Body, Substance and Monad (Oxford: Oxford University Press, 2009), Chapter 6; Michael V. Griffin, "Necessitarianism in Spinoza and Leibniz," in Charlie Huenemann, ed., Interpreting Spinoza, (Cambridge: Cambridge University Press, 2008), 71-93; and Jeffrey K. McDonough, "Leibniz on Optics and Contingency in Nature," Perspectives on Science, forthcoming.

${ }^{33}$ I would like to thank Marcy Lascano, Alison Simmons, and three anonymous referees for this journal for their helpful comments on earlier drafts of this paper. I would also like to thank audiences for helpful feedback at The Mid-West Seminar at the University of Chicago, The Margaret Wilson Memorial Conference at Cornell University, The Second Annual Conference of the North American Leibniz Society at Princeton University, as well as at meetings of the Society for Early Modern Philosophy at Yale University and the New York/New Jersey Consortium at John Jay College. I owe further special thanks to Sam Levey for numerous discussions of the issues raised in this paper as well as for his many helpful suggestions for improving it. 